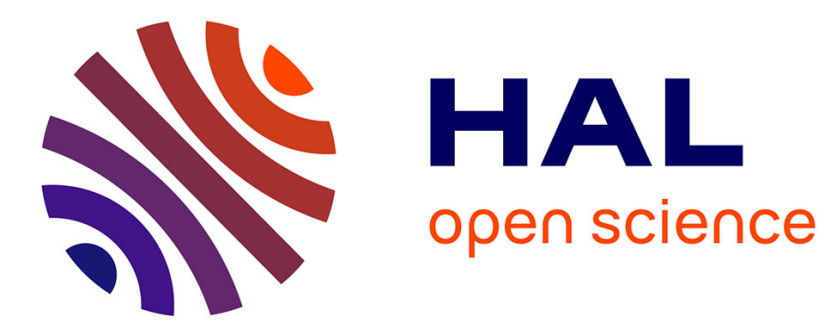

\title{
Syntheses and DNA binding of new cationic porphyrin-tetrapeptide conjugates
}

\author{
Gábor Mezö, Levente Herényi, Jan Habdas, Zsuzsa Majer, Beata \\ Myśliwa-Kurdziel, Katalin Tóth, Gabriella Csík
}

\section{- To cite this version:}

Gábor Mezö, Levente Herényi, Jan Habdas, Zsuzsa Majer, Beata Myśliwa-Kurdziel, et al.. Syntheses and DNA binding of new cationic porphyrin-tetrapeptide conjugates. Biophysical Chemistry, 2011, 155 (1), pp.36. 10.1016/j.bpc.2011.02.007 . hal-00734591

\section{HAL Id: hal-00734591 \\ https://hal.science/hal-00734591}

Submitted on 24 Sep 2012

HAL is a multi-disciplinary open access archive for the deposit and dissemination of scientific research documents, whether they are published or not. The documents may come from teaching and research institutions in France or abroad, or from public or private research centers.
L'archive ouverte pluridisciplinaire HAL, est destinée au dépôt et à la diffusion de documents scientifiques de niveau recherche, publiés ou non, émanant des établissements d'enseignement et de recherche français ou étrangers, des laboratoires publics ou privés. 


\section{Accepted Manuscript}

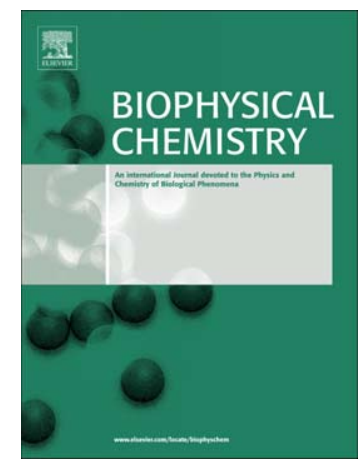

Syntheses and DNA binding of new cationic porphyrin-tetrapeptide conjugates

Gábor Mezô, Levente Herényi, Jan Habdas, Zsuzsa Majer, Beata MyśliwaKurdziel, Katalin Tóth, Gabriella Csík

$\begin{array}{ll}\text { PII: } & \text { S0301-4622(11)00028-7 } \\ \text { DOI: } & \text { doi: } 10.1016 / \mathrm{j} . \mathrm{bpc} .2011 .02 .007 \\ \text { Reference: } & \text { BIOCHE 5481 }\end{array}$

To appear in: Biophysical Chemistry

Received date: 9 January 2011

Revised date: $\quad 20$ February 2011

Accepted date: $\quad 21$ February 2011

Please cite this article as: Gábor Mező, Levente Herényi, Jan Habdas, Zsuzsa Majer, Beata Myśliwa-Kurdziel, Katalin Tóth, Gabriella Csík, Syntheses and DNA binding of new cationic porphyrin-tetrapeptide conjugates, Biophysical Chemistry (2011), doi: 10.1016/j.bpc.2011.02.007

This is a PDF file of an unedited manuscript that has been accepted for publication. As a service to our customers we are providing this early version of the manuscript. The manuscript will undergo copyediting, typesetting, and review of the resulting proof before it is published in its final form. Please note that during the production process errors may be discovered which could affect the content, and all legal disclaimers that apply to the journal pertain. 


\section{Syntheses and DNA binding of new cationic}

\section{porphyrin-tetrapeptide conjugates}

Gábor Mező ${ }^{1}$, Levente Herényi ${ }^{2}$, Jan Habdas ${ }^{3}$, Zsuzsa Majer, ${ }^{4}$ Beata Myśliwa-

Kurdziel ${ }^{5}$, Katalin Tóth ${ }^{6}$, Gabriella Csík $^{2 *}$

${ }^{1}$ Research Group of Pepetide Chemstry, Hungarian Academy of Science, Eötvös

Loránd University, Pázmány Péter sétány 1/A, Budapest 1117, Hungary

${ }^{2}$ Institute of Biophysics and Radiation Biology, Semmelweis University, 1444

Budapest POB 263 Hungary

${ }^{3}$ Institute of Chemistry, University of Silesia, Katowice 40-006, Poland

${ }^{4}$ Department of Organic Chemistry, Eötvös Loránd University, 1117 Pázmány Péter

sétány 1/A, Budapest, Hungary

${ }^{5}$ Department of Plant Physiology and Biochemistry, Jagiellonian University, ul.

Gronostajowa 7, Kraków 30-387, Poland

${ }^{6}$ Biophysik der Makromoleküle, DKFZ, Neuenheimer Feld 280, D-69120 Heidelberg,

Germany

*Corresponding author. 1444 Budapest POB 263 Phon/Fax: 36-1-266-6656,

E-mail addresses.

gabriella.csik@eok.sote.hu (G. Csik); gmezo@elte.hu (G. Mezo);

levente.herenyi@eok.sote.hu (L. Herenyi); jhabdas@us.edu.pl (J. Habdas);

majer@chem.elte.hu (Zs. Majer); b.mysliwa@wp.pl (B. Myśliwa-Kurdziel)

kt@dkfz-heidelberg.de (K. Toth) 


\section{Abstract}

Recently cationic porphyrin-peptide conjugates were synthesized to enhance the cellular uptake of porphyrins or deliver the peptide moiety to the close vicinity of nucleic acids. DNA binding of such compounds was not systematically studied yet.

We synthesized two new porphyrin-tetrapeptide conjugates which can be considered as a typical monomer unit corresponding to the branches of porphyrin-polymeric branched chain polypeptide conjugates. Tetra-peptides were linked to the tri-cationic meso-tri(4N-methylpyridyl)-mono-(4-carboxyphenyl)porphyrin and bi-cationic meso-5,10-bis(4N-methylpyridyl)-15,20-di-(4-carboxyphenyl)porphyrin. DNA binding of porphyrin derivatives, and their peptide conjugates was investigated with comprehensive spectroscopic methods. Titration of porphyrin conjugates with DNA showed changes in Soret bands with bathocromic shifts and hypochromicities. Decomposition of absorption spectra suggested the formation of two populations of bound porphyrins. Evidences provided by the decomposition of absorption spectra, fluorescence decay components, fluorescence energy transfer and induced CD signals reveal that peptide conjugates of di- a tricationic porphyrins bind to DNA by two distinct binding modes which can be identified as intercalation and external binding. Tri-cationic structure and elimination of negative charges in the peptide conjugates is preferable for the binding. Our findings provide essential information for the design of DNA-targeted porphyrinpeptide conjugates. 


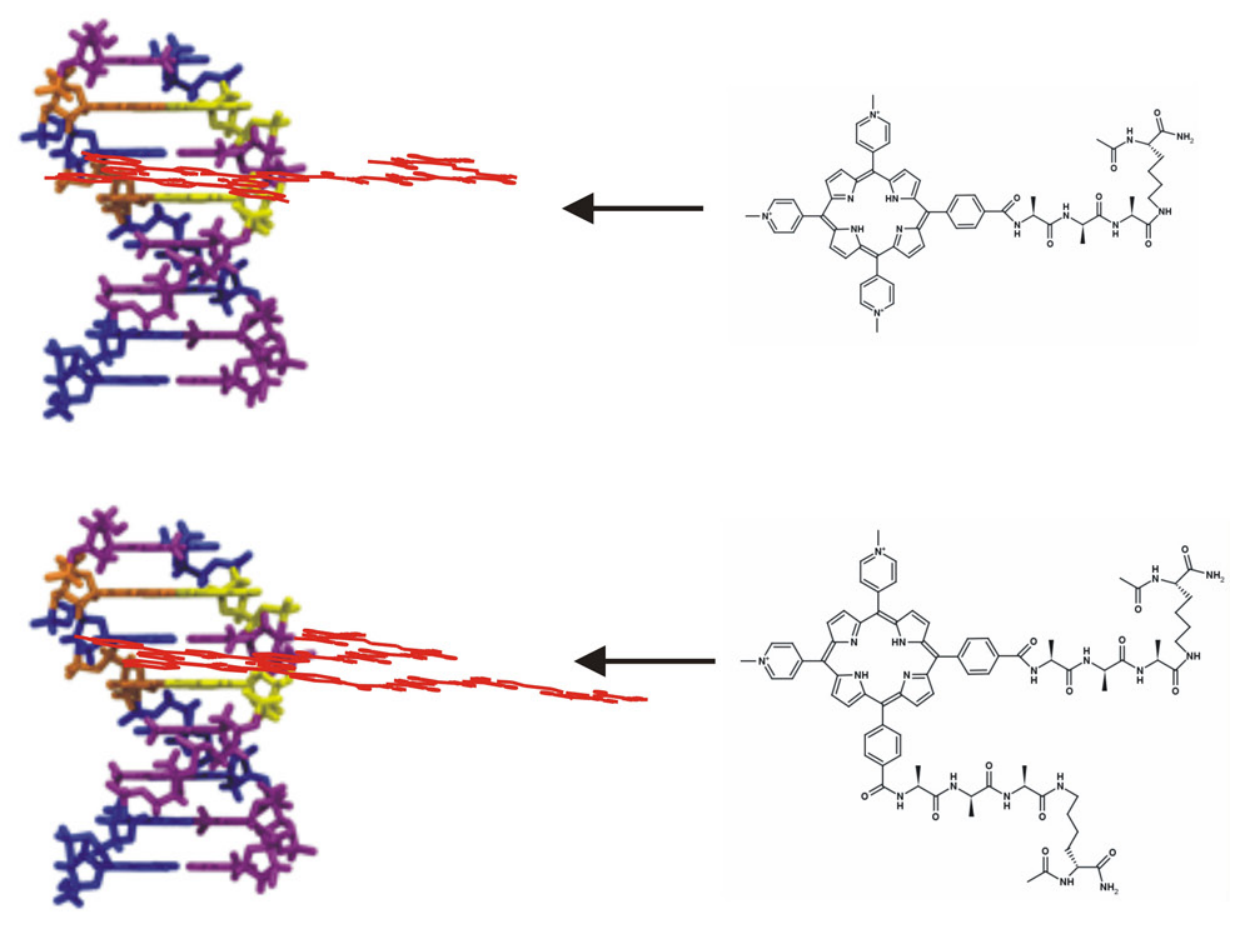

\section{Graphical Abstract}

\section{Research Highlights}

We synthesized two new porphyrin-tetrapeptide conjugates.

DNA binding of porphyrin conjugates was studied with spectroscopic methods.

Peptide conjugates of cationic porphyrins bind to DNA by two distinct binding modes. Binding modes can be identified as intercalation and external binding. 
Keywords: cationic porphyrin; photophysical parameters; porphyrin-peptide conjugate;

fluorescence spectroscopy, induced CD-signal, DNA-porphyrin binding; intercalation; 


\section{Introduction}

Porphyrins perform a wide variety of functions in natural and synthetic systems. They have been used in light-activated cancer treatment (photodynamic therapy) [1], in sensor design due to their fluorescent and electrochemical properties [2] and in gene therapy [3], they are the functional elements of light harvesting systems [4] and they could be used as artificial endonucleases [5].

Porphyrins are also one of the most studied DNA binding agents [6,7]. The binding of cationic porphyrin derivatives to nucleic acids has been the subject of extensive research since Fiel and colleagues discovered that these compounds can form various complexes with DNA [8]. It has been shown that the binding can be either intercalative or external, in the minor groove (in some special cases with self-stacking), depending on the charge distribution of the porphyrin, presence and the type of the central metal ion in porphyrin and on the peripheral substituents [9]. Most studies focused on interactions between free (non-covalently attached) cationic porphyrins and olygomeric or polymeric nucleic acids.

Recently some bioactive moieties [10-14] onto the periphery of the cationic porphyrin were introduced in order to utilize porphyrin as DNA targeting agent. Among others, peptide conjugates were also synthesized either to increase the cellular uptake of porphyrin derivative or to deliver the peptide moiety to the nucleic acids [15-19]. Although the first porphyrin-peptide conjugates were prepared about 20 years ago, there are only few papers dealing with their spectroscopic properties and interactions with DNA [10,20-22]. More limited studies were reported on the quantitative characterization of DNA binding of porphyrin-peptide conjugates. However, both 
qualitative and quantitative characteristics of the binding can be modified by the altered charge distribution and conformation of peptide-conjugated porphyrins.

Branched chain polypeptides with polylysine backbone (e.g. poly[Lys(DL-Ala $\left.a_{m}\right)$, (where $m$ is in average 3) developed in our laboratory [23] are efficient carrier to target drugs into the infected cells by fluidic endocytosis [24]. The increased endocytotic properties of tumor cells provide some selectivity for the cellular uptake of the polypeptide - drug conjugates. The basic branched chain polypeptide with poly(Lys) backbone and possess oligo-DL-Ala branches (in average 3 racemic alanine residues). Because of the branched chain polypeptides are planed to use for the delivery of porphyrins into the cells, we designed porphyrin conjugates of a tetrapeptide (AcLys(H-Ala-D-Ala-Ala)- $\mathrm{NH}_{2}$ ) as monomeric unit of branched polypeptide AK. The Nterminus of the oligo-alanine branch was used for the attachment of the porphyrin derivatives meso-tri(4- $N$-methylpyridyl)-mono-(4-carboxyphenyl)porphyrin (TMPCP) or meso-5,10-bis(4- $N$-methylpyridyl)-15,20-di-(4-carboxyphenyl)porphyrin (BMPCP). Here we investigate the interaction between natural nucleic acid polymer and tetrapeptide conjugates of TMPCP and BMPCP as models of porphyrin-peptide conjugates. Recently, we described a method $[25,26]$ which facilitates the identification and quantitative characterization of cationic porphyrin binding forms. A combined analysis of alteration in absorption and fluorescence emission spectra, fluorescence decay curves and induced circular dichroism (CD) of bound porphyrin makes possible the identification of binding forms and determination of their concentrations. Here we tend to apply similar approach in the analysis of DNA interaction with cationic porphyrins and their peptide conjugates. 
Since the photophysical characteristics of new derivatives and especially that of their conjugated forms are not known, these parameters have to be determined prior their application in DNA binding studies.

The aim of present work is (1) the presentation of the photophysical parameters of the selected cationic porphyrin derivatives and their peptide conjugates and (2) quantitative and qualitative characterization of their DNA binding.

\section{Materials and Methods}

\subsection{Materials}

All amino acid derivatives and 4-methylbenzhydrilamine (MBHA) resin were purchased from Iris Biotech Gmbh (Marktredwitz, Germany). Coupling agents ( $N, N^{\prime}-$ diisopropylcarbodiimide (DIC), 1-hydroxybenzotriazole (HOBt), (benzotriazol-1yloxy)tris(dimethylamino)-phosphonium hexafluorophosphate (BOP), 1-ethyl-3-(3dimethylaminopropyl)carbodiimide (EDC), $N$-ethyl-diisopropylamine (DIEA), diethylamine (DEA)), and cleavage reagents (trifluoroacetic acid (TFA), $p$-cresol, hydrogen fluoride (HF), 1,8-diazabicyclo-[5.4.0]undec-7-ene (DBU), piperidine) were Fluka products (Buchs, Switzerland). Solvents (dichloromethane (DCM), $N, N-$ dimethylformamide (DMF), diethylether) for synthesis were obtained from Molar Chemicals (Budapest, Hungary). Acetonitrile for HPLC was delivered by SigmaAldrich (Budapest, Hungary). meso-Tri(4- $N$-methylpyridyl)-mono-(4-carboxyphenyl)porphyrin (TMPCP) was synthesized as described before [27,28], meso-5,10-bis(4- $N$-methylpyridyl)-15,20-di(4-carboxyphenyl)porphyrin (BMPCP) was purchased from Frontier Scientific 
(Carnforth, UK). Porphyrins were stored at $4^{\circ} \mathrm{C}$ in powder form or as a stock solution in distilled water or in methanol. Before the experiments the porphyrin stock solutions were diluted into methanol or into a buffer solution composed of $20 \mathrm{mM}$ Tris- $\mathrm{HCl}$ and $50 \mathrm{mM} \mathrm{NaCl}$ adjusted to $\mathrm{pH}=7.4$

Bacteriophage DNA was prepared from T7 phage (ATCC 11303-B7) grown on Escherichia coli (ATCC 11303) host cells. The cultivation and purification were carried out according to the method of Strauss and Sinsheimer [29]. The phage suspension was concentrated on a $\mathrm{CsCl}$ gradient and dialyzed against buffer solution composed of 20 $\mathrm{mM}$ Tris - $\mathrm{HCl}$ and $50 \mathrm{mM} \mathrm{NaCl},(\mathrm{pH}=7.4)$.

Nucleoprotein complex was incubated with SDS $(1,4 \mu \mathrm{g}$ SDS for $1 \mu \mathrm{g}$ protein) at $65^{\circ} \mathrm{C}$ for $30 \mathrm{~min}$; followed by precipitation with $1 \mathrm{M} \mathrm{KCl}$ on ice for $10 \mathrm{~min}$. The precipitate was centrifuged twice for $10 \mathrm{~min}$ in an Eppendorf microcentrifuge at 13000 $\mathrm{rpm}$. The DNA was precipitated with ethanol from the supernatant. The pellet was washed with 70\% ethanol, and resuspended in buffer solution $20 \mathrm{mM}$ Tris - $\mathrm{HCl}, 50$ $\mathrm{mM} \mathrm{NaCl},(\mathrm{pH}=7.4)$. The amount of DNA was determined spectrophotometrically. The quality of the DNA was checked by gel electrophoresis and by its absorption spectrum.

\subsection{Synthesis of Ac-Lys(H-Ala-D-Ala-Ala)-NH}

The tetrapeptide was prepared by solid phase synthesis on MBHA resin $(1.04 \mathrm{mmol} / \mathrm{g}$ capacity). First Fmoc-Lys(Boc)-OH amino acid derivative was attached to the resin using DIC/HOBt coupling agents (three equivalents to the resin capacity). After removal of Fmoc group with a cleavage mixture of $2 \%$ piperidine and 2\% DBU in DMF $\left(2+2+5+10\right.$ min) the $\alpha$-amino group was acetylated with $\mathrm{Ac}_{2} \mathrm{O}$ :DIEA:DMF $(1: 1: 3, v / v)$ mixture for 30 min. Prior to the building up of the side chain, the Boc 
protecting group was cleaved with $33 \%$ TFA in DCM (2+20 min) followed by neutralization with 10\% DIEA in DCM. Boc-Ala-OH, Boc-D-Ala-OH and Boc-Ala$\mathrm{OH}$ were incorporated, respectively. After removal of the final Boc protecting group the peptide-resin was dried in vacuo and the peptide was cleaved from the resin with $\mathrm{HF}$ in the presence of $p$-cresol as scavanger $(\mathrm{HF}: \mathrm{p}$-cresol $=10 \mathrm{ml}: 0.5 \mathrm{~g})$ at $0^{\circ} \mathrm{C}$ for 60 min. The crude product was precipitated with dry ether and it was purified by RPHPLC. The purified tetrapeptide was characterized by analytical HPLC and ESI-MS.

\subsection{Conjugation of porphyrine derivatives to Ac-Lys(H-Ala-D-Ala-Ala)- $\mathrm{NH}_{2}$}

Method 1: Porphyrin derivative with one (TMPCP) or two (BMPCP) carboxyl groups were reacted with Ac-Lys(H-Ala-D-Ala-Ala)- $\mathrm{NH}_{2}$ using 50\% excess of the tetrapeptide and water soluble carbodiimide (EDC) to the carboxyl groups in DMF in the presence of two equiv DIEA/EDC. Prior to the conjugation the trifluoroacetate salt of the tetrapeptide was changed to $\mathrm{HCl}$ salt by the aid of pyridinium hydrochloride in methanol to avoid the trifluoroacetylation of the tetrapeptide. The conjugation was carried out at room temperatrure overnight. The solvent was evaporated and the remaining product was dissolved in a mixture of eluents A and B and by RP-HPLC. The conjugates $\mathrm{NH}_{2}-\mathrm{Lys}(\mathrm{TMPCP}-\mathrm{Ala}-\mathrm{D}-\mathrm{Ala}-\mathrm{Ala})-\mathrm{CONH}_{2}$, (TMPCP-4P) and $\mathrm{NH}_{2}-$ Lys[Lys(Ala-D-Ala-Ala-BMPCP)BMPCP-Ala-D-Ala-Ala)]-CONH${ }_{2}\left(\mathrm{BMPCP}^{-4 \mathrm{P}_{2}}\right)$ were analyzed by analytical HPLC and ESI-MS. Method 2: In the second experiment EDC was replaced by BOP reagent, but no other changes were carried out.

\subsection{Analysis and purification by reverse phase high performance liquide} chromatography (RP-HPLC) 
Analytical RP-HPLC was performed on a Knauer (H. Knauer, Bad Homburg, Germany) system using a Phenomenex Jupiter C18 column (250 mm x $4.6 \mathrm{~mm})$ with 5

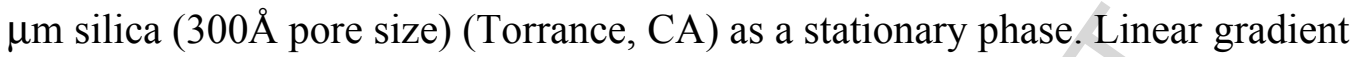
elution $(0 \min 0 \% \mathrm{~B} ; 5 \min 0 \% \mathrm{~B} ; 50 \mathrm{~min} 90 \% \mathrm{~B})$ with eluent $\mathrm{A}(0.1 \%$ TFA in water $)$ and eluent B (0.1\% TFA in acetonitrile-water $(80: 20, \mathrm{v} / \mathrm{v}))$ was used at a flow rate of 1 $\mathrm{mL} / \mathrm{min}$. Peaks were detected at $\lambda=220 \mathrm{~nm}$ and at $\lambda=280 \mathrm{~nm}$ in the case of unconjugated porphyrins. The crude products were purified on a semi-preparative Phenomenex Jupiter C18 column $(250 \mathrm{~mm}$ x $10 \mathrm{~mm})$ with $10 \mu \mathrm{m}$ silica (300 A pore size). An isocratic elution with $10 \%$ of eluent B (using the same eluents) was applied from 0 to 5 min then 5-50 min a gradient elution of $10-55 \%$ of eluent B was used with 4 $\mathrm{mL} / \mathrm{min}$ flow rate. Peaks were detected at $\lambda=220 \mathrm{~nm}$.

\subsection{Electrospray ionization mass spectrometry (ESI-MS) analysis}

The identification of the products was achieved by mass spectrometry. Electrospray ionization mass spectrometry was performed with a Bruker Daltonics Esquire 3000 Plus (Bremen, Germany) ion trap mass spectrometer, operating in continuous sample injection at $4 \mu \mathrm{l} / \mathrm{min}$ flowrate. The peptide conjugates were dissolved in $50 \%$ acetonitrile water mixture. Mass spectra were recorded in positive ion mode in the $\mathrm{m} / \mathrm{z}$ 200-1500 range.

\subsection{Absorption spectroscopy}

Ground-state absorption spectra of porphyrin and porphyrin-peptide conjugate solutions were recorded with $1 \mathrm{~nm}$ steps and $2 \mathrm{~nm}$ bandwidth by use of a Cary $4 \mathrm{E}$ (Varian, Mulgrave, Australia) spectrophotometer at various DNA concentrations. In 
DNA containing samples the composition of solutions was expressed in terms of an $r$ number representing the molar ratio of DNA base pairs to porphyrin molecules.

In the applied concentration range the free porphyrins were in monomeric state.

Spectral changes due to the due to the adsorption of porphyrins on the cuvette wall were less than $5 \%$.

\subsection{Decomposition of absorption spectra}

The spectral decomposition was performed for absorption spectra $[A(\lambda)$, absorbance versus wavelength] of the series of $\mathrm{BMPCP}-$, BMPCP-4P ${ }_{2}-$, TMPCP-, TMPCP-4PDNA-complex solutions with various base-pair/porphyrin molar ratios $(r)$. All the spectra were analyzed in the $\lambda=370-490 \mathrm{~nm}$ wavelength range.

For fitting we used the Gaussian multi-peaks fit routine from the Microcal Origin software. The error of the fit was determined as:

$$
\chi^{2}=\frac{\sum_{\lambda=370}^{490}\left[A(\lambda)_{\text {measured }}-A(\lambda)_{\text {calculated }}\right]^{2}}{\sum_{\lambda=370}^{490} A(\lambda)_{\text {measured }}}
$$

We did not apply the usual wavelength-frequency conversion. The maximum errors of the fitting parameters because of the absence of this conversion were not higher than $0.5 \mathrm{~nm}$.

\subsection{Fluorescence spectroscopy}

Corrected steady-state emission and excitation spectra were obtained using Fluorolog 4 spectrofluorometer (Jobin Yvon, France). Samples were excited at the corresponding excitation maxima at room temperature. If the absorbance of the sample exceeded 0.05 , 
the observed fluorescence intensity was corrected for inner filter effect of the solution.

The fluorescence quantum yields of porphyrin derivatives $\left(\Phi_{F}^{S}\right)$ in different media were estimated as

$$
\Phi_{F}^{S}=\left(\frac{n^{S}}{n^{R}}\right)^{2} \frac{F^{S}}{F^{R}} \frac{A^{R}}{A^{S}} \Phi_{F}^{R}
$$

where $\Phi_{F}^{R}$ is the quantum yield of rhodamine B in ethylene glycol as reference compound [30], $A$ is the absorbance at the wavelength of the excitation, $F$ is the integrated area of the emission spectra, $n$ is the refractive index of the solution, the $S$ superscript refers to the sample and $R$ to the reference. The integrated fluorescence of the sample was compared to that of the standard after adjusting concentration so that the absorbance of the sample and reference at the excitation wavelength were equal.

Contact energy transfer from nucleic acid bases to bound porphyrin was measured from fluorescence excitation and emission spectra recorded between 220 and $330 \mathrm{~nm}$ $\left(\lambda_{\mathrm{em}}=660 \mathrm{~nm}\right)$ and $580-780 \mathrm{~nm}\left(\lambda_{\mathrm{ex}}=260 \mathrm{~nm}\right)$, respectively. The porphyrin concentration was constant in the parallel samples, and the base pair/porphyrin ratio varied between 0 and 30 .

\subsection{Fluorescence decay measurements}

Fluorescence lifetimes were measured using ISS K2 multifrequency cross-correlation phase and modulation fluorometer (ISS, Champaign, IL) equipped with a $300 \mathrm{~W}$ xenon lamp as an excitation source and a Pockel cell as a modulator of light intensity. Fluorescence signal was observed through a cutoff filter at wavelengths longer than 550 $\mathrm{nm}$. Each measurement was performed for 10 modulation frequencies ranging from 1 to $200 \mathrm{MHz}$. The phase shift and demodulation ratio were measured in reference to the 
scattering solution of glycogen in water. The evaluated average random errors in the experimental data used then in the fluorescence lifetime analysis were equal to 0.2 and 0.004 for phase shift and modulation, respectively. The intensity decay data were analyzed according to a multi-exponential decay law using discrete exponential components. A nonlinear least square analysis program was delivered by ISS Company. Excitation wavelength was set to the maximum of the Soret absorption band of each porphyrin. The fluorescence lifetime of free porphyrin derivatives $(\mathrm{c}=2 \mu \mathrm{M})$ was determined in Tris- $\mathrm{HCl}$ buffer $(\mathrm{pH} 7.4)$ buffer and in methanol. Lifetimes were also determined in the presence of T7 DNA at base pair/porphyrin ratio $=6$.

\subsection{Circular dichroism}

Circular dichroism (CD) measurements were made on a Jasco J-810 dichrograph in calibrated with aminocamphorsulfonic acid at room temperature in $1 \mathrm{~cm}$ quartz cell. Spectra were recorded between 380 and $500 \mathrm{~nm}$. CD spectra of porphyrin derivatives and conjugates were recorded at various concentrations of DNA. In parallel samples the porphyrin concentration was constant. As baselines, the solvent reference spectra were used and were automatically subtracted from the CD spectra of the samples. CD band intensities were expressed in molar ellipticity / $[\Theta] \operatorname{deg} \mathrm{x} \mathrm{cm}^{2} / \mathrm{dmol} /$ using the equation:

$$
[\Theta]=\Theta / 10 * c * 1
$$

\section{Results}

\subsection{Synthesis}


Ac-Lys(H-Ala-D-Ala-Ala)- $\mathrm{NH}_{2}$ branched tetrapeptide as a model peptide of branched chain polypeptide poly[Lys(DL-Ala 3.0$)](\mathrm{AK})$, a potential carrier for drug delivery, was synthesized by solid phase peptide synthesis on MBHA resin with good yield (84\%). The free $\alpha$-amino group at the $\mathrm{N}$-terminal of the branch was conjugated with the carboxyl group(s) of porphyrin derivatives. Two coupling strategies with different agents were applied for conjugation. The use of BOP reagent provided fairly good results in case of TMPCP (53\% yield), but a large number of side products were also detected after conjugation with BMPCP. The replacement of BOP by the water soluble carbodiimide EDC reagent resulted in BMPCP conjugate (47\% yield), however no improvement of the yield was observed in case of TMPCP. In conclusion, BOP is efficient for the conjugation of TMPCP to the model peptide, however EDC could be preferred for BMPCP.

The structures of conjugates prepared are shown in Fig. 1. TMPCP, BMPCP and their conjugates were characterized by RP-HPLC and ESI-MS (Table 1.). The measured triple charged masses of TMPCP $\left(\mathrm{M}^{3+}=235.7 \mathrm{Da}\right)$ and its conjugate $\left(\mathrm{M}^{3+}=363.1 \mathrm{Da}\right)$ were corresponding to the positively charged pyridines in porphyrin derivative without any further protonation of the compounds. In case of BMPCP a doubly charged peak were detected $\left(\mathrm{M}^{2+}=367.4 \mathrm{Da}\right)$. However, the most intensive peak in MS spectra of BMPCP- $4 \mathrm{P}_{2}$ conjugate corresponded to a triple charged $\left[\mathrm{M}^{2+}+\mathrm{H}^{+}\right]$mass with a value of $500.3 \mathrm{Da}$, and also doubly charged peak was detected $\left(\mathrm{M}^{2+}=750.0 \mathrm{Da}\right)$. Interaction of porphyrin derivatives and conjugates with DNA was investigated by various optical spectroscopic methods. Since the photophysical parameters of BMPCP 
and TMPCP and their peptide conjugates were not known from the literature, prior the DNA binding studies we performed their spectroscopic characterization.

\subsection{Photophysical characteristics}

The ground-state absorption properties of porphyrin derivatives and their peptide conjugates were studied in methanol and in Tris- $\mathrm{HCl}$ buffer $(\mathrm{pH} 7.4)$. As examples, the absorption spectra of TMPCP in two different solvents are presented in Fig. 2A. The spectra recorded both in Tris- $\mathrm{HCl}$ buffer and methanol are typical of monomeric freebase porphyrins, consisting of the intense Soret band around $400 \mathrm{~nm}$ and weaker $\mathrm{Q}_{\mathrm{x}}, \mathrm{Q}_{\mathrm{y}}$ bands with their vibronic components in $\lambda=500-700 \mathrm{~nm}$ interval. Up to $10 \mu \mathrm{M}$ concentration broadening of the Soret absorption band was not experienced (data not shown). Absorption spectra of di- and tri-cationic compounds (BMPCP and TMPCP) are very similar to each other in shape having a phyllo-type Q-band structure. Soret bands of the porphyrin derivatives and conjugates are compared in Fig. 2B. In the case of TMPCP, the structure of absorption spectrum does not change noticeably due to the conjugation of peptide moiety. The width of BMPCP Soret band is reduced due to the conjugation, but the Q-band structure remains the same.

Absorption maxima of the Soret and $\mathrm{Q}_{\mathrm{x}}(0,0)$ bands with corresponding molar absorption coefficients obtained from the slope of the linear part of Beer-Lambert plots of absorbance versus concentration are listed in Table 2. The absorptivities of investigated porphyrin derivatives in both the Soret and $\mathrm{Q}_{\mathrm{x}}(0,0)$ bands are in the range of the absorptivities of other meso-substituted porphyrins [31-33], and they are slightly bigger than those of hematoporphyrin derivatives. 
Fig. 3 shows the fluorescence emission spectra of TMPCP-4P in methanol and in Tris$\mathrm{HCl}$ buffer $\mathrm{pH} 7.4$ measured at a drug concentration of $1 \mu \mathrm{M}$. The samples were excited at the maximum of the Soret bands. Similarly to TMPCP-4P, emission spectra of the investigated porphyrin derivatives and BMPCP- $4 \mathrm{P}_{2}$ can be characterized by a broad unstructured fluorescence band having the maximum around the $695-700 \mathrm{~nm}$ in aqueous solution, which is typical for cationic porphyrins [34]. In organic solvent a splitting of the broad emission band and the appearance of the two-band structure in the $\lambda=600-800 \mathrm{~nm}$ range can be observed. The positions of the two maxima and the relative intensities of the two bands are dependent on the chemical structure of the derivatives (data not shown).

The positions of fluorescence emission maxima, the lifetimes and fluorescence quantum yields of the four derivatives in different solutions are summarized in Table 2.

\subsection{Binding studies}

\subsubsection{Decomposition of absorption spectra}

Absorption spectra of porphyrin derivatives were recorded at constant porphyrin and various DNA concentrations. Fig. 4A shows the Soret bands (and the DNA absorption band) of a series of BMPCP- $4 \mathrm{P}_{2}$ absorption spectra recorded at constant porphyrin concentration and increasing base pair/porphyrin ratio $(r)$. Increasing relative base pair concentration is followed by hypochromism and red shift of the spectra. These overall spectral changes are typical for the cationic porphyrin-DNA binding described before [35-37].

For further analysis of Soret bands we made the following assumptions: 
All of the measured spectra $[A(\lambda)]$ can be considered as a sum of the component spectra belonging to possible porphyrin states. The spectrum of each state $\left[A_{x}(\lambda)\right]$ can be fitted as a sum of at least two Gaussians:

$$
\mathrm{A}(\lambda)=\sum_{\mathrm{i}=1}^{\mathrm{n}} \frac{\mathrm{A}_{\mathrm{i}}}{\mathrm{w}_{\mathrm{i}} \sqrt{\pi / 2}} \exp \left(\frac{-2\left(\lambda-\lambda_{\mathrm{i}}\right)^{2}}{\mathrm{w}_{\mathrm{i}}^{2}}\right)+\mathrm{y}_{0}
$$

where $\lambda_{\mathrm{i}}$ is the center of the peak and $w_{i}$ is the full width of the band. The only parameter changing with the concentration of the porphyrin population in a specific state is the total area under the curves $\left(\mathrm{A}_{x}\right)$ and all of the other parameters are constant for a spectrum belonging to one state. As a general purpose we used the least number of possible components for an acceptable fit.

Component Gaussians of free compounds and their parameters: center of the peak and full width of the band were determined from the spectrum of the DNA-free samples and are given in Table 3. We used these parameters for further fits as constants. It was found that the spectra of the free derivatives could be fitted by three component bands from which one was similar for each derivative $\left(\lambda_{c}\right.$, and $\left.w_{c}\right)$, the other two $\left(\lambda_{1-2}\right.$ and $\left.w_{1-2}\right)$ varied with the porphyrin structure. Decomposition of the spectra recorded in the presence of DNA, resulted two additional Gaussian components $\left(\lambda_{3-4}\right.$ and $\left.w_{3-4}\right)$. The overall spectral changes and the increase of component bands suggest that out of the non-bound porphyrin molecules distinct population of bound porphyrin(s) can be formed in the presence of DNA.

The relative areas under the Gaussians components $\left(\mathrm{A}_{i}^{*}\right)$ were determined at various base pair/porphyrin ratios $(r)$. The change in relative area of a component indicates the change of relative concentration of the corresponding porphyrin population. In Fig. 5 
$\mathrm{A}_{i}{ }^{*}$-s are presented as the function $\lg r$. In the case of all four derivatives, component bands of the free porphyrins $\left(\mathrm{A}_{1}{ }^{*}\right.$ and $\left.\mathrm{A}_{2}{ }^{*}\right)$ are diminished by the increasing base pair/porphyrin ratios and parallel to that the relative area of the bands induced by the presence of DNA $\left(\mathrm{A}_{3}{ }^{*}\right.$ and $\left.\mathrm{A}_{4}{ }^{*}\right)$ increases. We can suppose that these changes reflect the reduction of free porphyrin species and elevation of bound porphyrin concentration with increasing $r$. However significant differences can be recognized between BMPCP and TMPCP and also between the non-conjugated and conjugated forms of the same mother derivative. Gaussians components of free TMPCP spectrum tend to zero at about $r=20$, the same components of BMPCP are almost unchanged up to the same base pair/porphyrin and their decrease is only about $20 \%$ even at $r=50$. Component bands of free TMPCP-4P become negligible already at $r=2$ indicating that the conjugation increases the binding ability of the mother molecule (Fig. 5A). Similar tendency can be observed in the case of BMPCP-4P ${ }_{2}$ (Fig. 5B). According to these results the binding ability of investigated derivatives follows the next order: TMPCP-4P> TMPCP > BMPCP-4P $2>$ BMPCP.

\subsubsection{Fluorescence emission spectra}

The fluorescence emission spectra of compounds were taken in the presence of various concentrations of isolated DNA. Fig. 3 shows the normalized fluorescence emission spectrum of TMPCP-4P in the presence of DNA at $r=5$. We can observe that the interaction with DNA causes splitting of the broad fluorescence band. The relative amplitude of the bands depends on the base pair/porphyrin ratio (data not shown). Similar spectral changes were detected for TMPCP and BMPCP- $4 \mathrm{P}_{2}$, however the saturation of the process was observed at different excess of DNA base pairs. 


\subsubsection{Fluorescence decay measurements}

As a very sensitive signal of the changes of chromophore's environment, the fluorescence lifetime of porphyrins and pophyrin-peptide conjugates was measured at room temperature. The fluorescence decay of BMPCP, TMPCP and their conjugates was measured and analyzed in the presence of DNA. The lifetimes of fluorescent porphyrin species obtained at $r=6$ are presented in Table 4 .

In the case of BMPCP a single lifetime was received even in the presence of DNA at $r=6$ and this value was not significantly different from the lifetime in DNA-free sample (see Table 2). In all the other cases the best fit was achieved by a bi-exponential function. The longer lifetime components are in the range of $8.5-9.5 \mathrm{~ns}$, the shorter ones between $2.3-3.5 \mathrm{~ns}$. For TMPCP and TMPCP-4P these values are clearly different from the lifetime of free species, 4.2 and $4.9 \mathrm{~ns}$, respectively. These results show that two populations of bound TMPCP and TMPCP-4P can be formed in the presence of DNA. Furthermore at $r=6$ free species were not indicated by fluorescent lifetime. The received lifetime ranges are in good agreement with the lifetimes of intercalated and externally bound tetra-cationic porphyrin determined by Shen et al. [38]. On the basis of this conformability, we can suppose that the shorter lifetime may identify intercalated species and the longer ones reflect on externally bound porphyrins. In the case of BMPCP- $4 \mathrm{P}_{2}$ the longer lifetime component $(9.76 \mathrm{~ns})$ does not deviate markedly from the lifetime of the free compound ( $8.99 \mathrm{~ns})$. This can either mean that only one bound porphyrin species is present at $r=6$ or a bound species of longer lifetime cannot be distinguished from the free BMPCP- $4 \mathrm{P}_{2}$.

\subsubsection{Fluorescence energy transfer}


Since the first report of contact energy transfer from DNA bases to bound ligands by Le Pecq and Paoletti [39], this technique has been used frequently in DNA-ligand interaction studies. Porphyrins that contact closely with DNA bases are characterized by a clear increase of their fluorescence quantum yields for an excitation around 260 $\mathrm{nm}$, corresponding to an energy transfer from DNA bases to porphyrins [35]. This phenomenon can be considered as a criterion for intercalation.

We recorded the fluorescence emission spectra of porphyrin-DNA samples between $\lambda=550-800 \mathrm{~nm}$ when they were excited at $\lambda=260 \mathrm{~nm}$. The fluorescence intensity of free porphyrins upon excitation at $\lambda=260 \mathrm{~nm}$ is not zero. Detected intensity in the presence of DNA is the superposition of the emissions of free and bound forms. Fig. 6 shows the relative fluorescence intensity $\left(I_{\text {rel }}\right)$ of porphyrin derivatives $(1 \mu \mathrm{M})$ at various concentration of isolated phage DNA. The reference was the fluorescence intensity of DNA-free samples.

A significant increase in the emitted intensity can be observed at constant porphyrin and increasing base pair concentration in the case of TMPCP and TMPCP-4P and BMPCP- $4 \mathrm{P}_{2}$. However, the saturation of the process can be reached at different base pair / porphyrin molar ratios. The corresponding $r$ values were about 2 and 13 for TMPCP-4P and TMPCP, respectively. In the case of BMPCP-4 $\mathrm{P}_{2}$ the saturation was not reached up to $r=30$. Upon excitation at $\lambda=260 \mathrm{~nm}$, there was no significant change in the emitted fluorescence intensity of BMPCP solution supplemented with DNA in the investigated base pair/porphyrin ratios.

\subsubsection{Circular dichroism}


Porphyrins, although non-chiral, display induced circular dichroism (CD) spectra in Soret region when they are bound to DNA $[37,40,41]$.

As it could be expected, in DNA-free samples all the four compounds were nonchiral, and BMPCP seemed also non-chiral even at $r=30$ (data not shown).

Fig. 7 shows CD spectra of TMPCP, TMPCP-4P, and BMPCP-4P 2 recorded in the presence of DNA at $r=30$. All these three compounds display induced CD spectrum composed of a positive and a negative band. Positive bands are centered on $\lambda=421 \mathrm{~nm}$ (TMPCP-4P and BMPCP-4P 2 ) and $\lambda=425 \mathrm{~nm}$ (TMPCP), a negative ones are centered around 436, 442 and $447 \mathrm{~nm}$ for BMPCP-4P 2 TMPCP-4P and TMPCP, respectively.

It was demonstrated before that the appearance of a negative induced CD band is a signature for intercalation whereas a positive induced band is indicative of a nonintercalated binding mode [42]

Induced CD signals of TMPCP and investigated peptide conjugates were increasing with increasing base pair/porphyrin ratio. In the case of BMPCP conjugate the highest amplitude was reached around $r=30$. In the case TMPCP-4P and TMPCP the process was saturated already at $r=3$ and $r=12$, respectively.

Out of the base pair/porphyrin ratios leading to the apparent saturation of the binding process, the relative amplitude of positive and negative bands varies according to the structure of compound. The positive band is predominant in the spectrum of BMPCP$4 \mathrm{P}_{2}$, meanwhile the amplitude of the negative band is higher in the case of TMPCP-4P and TMPCP. This can reflect on the relative dominancy of different binding types.

\section{Discussion}


Several cationic porphyrins are known as DNA binding agents. Recently cationic porphyrin-peptide conjugates were synthesized to enhance the cellular uptake of porphyrins $[18,43]$ or deliver the peptide moiety to the close vicinity of nucleic acids[44-45]. It was also reported that some conjugates were able to interact with nucleic acids [46] however the DNA binding of such compounds was not systematically studied yet. Here we synthesized two new porphyrin-tetrapeptide conjugates which can be considered as a typical monomer unit corresponding to the branches of porphyrin-polymeric branched chain polypeptide conjugates. One of the new compounds was derived from tri-cationic TMPCP with the conjugation of one tetrapeptide, in the other molecule two tetrapeptides was linked to the bi-cationic BMPCP. DNA binding of porphyrin derivatives, and their peptide conjugates was investigated with comprehensive spectroscopic methods. Spectroscopic methods could be selected because it is known that the DNA anionic and cationic domains should affect the photophysical properties of bound porphyrins.

Most of the photophysical parameters of TMPCP and BMPCP in DNA-free solution were found to be typical for the cationic free-base porphyrins, and those parameters were not significantly altered by the conjugation of peptide moieties (Fig. 2 and 3, Table 2). A noticeable feature of the emission spectra of free porphyrins recorded in aqueous solution is that the maximum of the broad unstructured fluorescence band does not correspond to the 0,0 transition.

We recorded and decomposed the Soret bands in the absorption spectra of porphyrin derivatives and their conjugates at various base pair/porphyrin ratios in order to verify 
the presence of bound species. When DNA was added to the porphyrin or porphyrinpeptide conjugate solutions two new component bands were identified (Table 3, Fig. 4).

We could find such spectral parameters for those component bands that were independent of the base pair/porphyrin molar ratio. The amplitudes of two component bands were increasing, and the amplitude of the main band of free porphyrins were diminished with increasing base pair/porphyrin ratio (Fig. 5) indicating a repopulation of porphyrin molecules between free and bound states in the presence of DNA. One of the increasing amplitude was centered around $429 \mathrm{~nm}$ for all the investigated compounds. The centers of the other new bends were 446 and $435 \mathrm{~nm}$ in the case of triand di-cationic compounds, respectively.

It was shown before that tetra-cationic meso-tetrakis(4-N-methylpyridyl)porphyrin (TMPyP) bind non-covalently to DNA by two main mechanisms: intercalation between base pairs or external binding in a groove. Absorption spectra of bound forms show characteristic features relative to the free porphyrin: about $20 \mathrm{~nm}$ red shift and about $40 \%$ hypochromicity of the Soret band for intercalation and a few nanometer red shift and about 5\% hypochromicity for external binding [25,36,37].

The red shift and the approximate hypochromicity of increasing component bands of TMPCP, BMPCP and their conjugates in the presence of DNA were very similar to the values reported before for intercalated and externally bound tetra-cationic porphyrin $[25,36,37]$.

Results of the decomposition of absorption spectra suggest that both porphyrin derivatives and their peptide conjugates can bind to DNA and reflect on at least two distinct binding modes. These binding modes may correspond to the intercalation and 
external binding. However, the result of spectral decomposition itself can not be considered as an experimental evidence for the identification of binding forms.

It became also clear that the relative partition of porphyrin derivatives or their peptide conjugates between free and bound populations was the function not only the base pair/porphyrin ratio but also the structure of the compound (Fig. 4).

In the presence of DNA the lifetime of free TMPCP and TMPCP-4P (4.2 ns and 4.9 $\mathrm{ns}$, respectively) was altered, and in both cases a shorter (2.38 ns and $3.46 \mathrm{ns,}$ respectively) and a longer (8.64 ns and $9.50 \mathrm{~ns}$, respectively) lifetime component were identified. These results of fluorescence decay experiments also showed the formation of two binding states between DNA and TMPCP or TMPCP-peptide conjugate. On the basis of lifetime values, one of the bound species can be recognized as intercalated the other one as externally bound form $[25,38]$.

In the case of BMPCP-peptide conjugate a short lifetime component indicated the formation of intercalated complex, however there was no clear evidence for the presence of a second binding form. This might be explained by the nil or very small partition of another bound porphyrin population at $r=6$, or by a very similar lifetime of free and one bound species.

To further investigate the binding modes of porphyrin derivatives and their conjugates, the circular dichroism spectra were measured. The size and sign of induced CD spectra of DNA bound porphyrins depend on a number of factors, such as proximity and relative orientation of transition moment of the chromophore. However, as it was also shown, the orientation of porphyrin electric dipole transition is unaffected by peripheral substituents, and generalizations concerning CD spectral patterns could 
be anticipated [47]. It is generally accepted that a single negative band indicative for the intercalation $[48,49]$, and a positive band belongs to externally bound porphyrin at DNA grooves [37]. Our presented results (Fig. 7) that is the presence of both positive and negative bands in the induced CD spectra of TMPCP, of its conjugate and of BMPCP-peptide conjugate suggest that in these cases both bound poprhyrin populations were formed.

Splitting of fluorescence spectral bands [34] and the overall changes of absorption spectra in the presence of DNA indicates that TMPCP, TMPCP-peptide conjugate and BMPCP-peptide conjugate interacts with natural polynucleotide. Moreover, the evidences provided by the decomposition of absorption spectra, fluorescence decay components, fluorescence energy transfer and induced CD signals reveal that these compounds bind to DNA by two distinct binding modes. Based on the similarities between the characteristics of previously identified porphyrin binding forms and those of our compounds, the two binding modes can be identified as intercalation and external binding.

Up to $r=30$ the applied methods did not provide any experimental evidence for the interaction between BMPCP and DNA. Fluorescence methods and CD spectroscopy did not facilitate the investigation of higher base pair/porphyrin ratios. Decomposition of absorption spectra recorded at $r>30$ indicated the DNA binding of BMPCP.

Besides the similarities, a significant difference can be recognized between the DNA binding of TMPCP, TMPCP-4P and BMPCP-4P 2 , namely the saturation of the binding process occurs at different base pair/porphyrin ratios. The results provided by various 
methods are slightly different from each other, but the order of corresponding $r$ values are very much the same: TMPCP-4P $<$ TMPCP $<$ BMPCP $-4 \mathrm{P}_{2}<<$ BMPCP.

The experienced order of binding ability can be explained by the charge distribution of the molecules and by the consequently different electrostatic forces between porphyrin derivatives and DNA bases. Previous works $[50,51]$ also demonstrated that the binding between cationic porphyrins with DNA is also controlled by their electrostatic nature.

In Table 5 we summarized the charge composition of compounds, and the approximate base pair/porphyrin ratios $(r)$ at which the partition of free compound becomes negligible in the presence of DNA. It is clear that the sterik effect of peptide moiety does not oppose the interaction between DNA and cationic porphyrins. It was also shown that the tri-cationic structure and elimination of negative charges in the peptide conjugates preferable for DNA binding.

Our findings provide essential information for the future design of DNA-targeted porphyrin-peptide conjugates.

\section{Acknowledgements}

This work was supported by research grant OTKA NK77485. We are very grateful to Monika Drabbant for her technical assistance.

\section{References}

[1] A.E. O'Connor, W.M. Gallagher and A.T. Byrne, Porphyrin and nonporphyrin photosensitizers in oncology: preclinical and clinical advances in photodynamic therapy, Photochem. Photobiol. 85 (2009) 1053-1074. 
[2] W. Waskitoaji, T. Hyakutake, J. Kato, M. Watanabe and H. Nishide, Biplanar visualization of oxygen pressure by sensory coatings of luminescent pt-porpholactone and -porphyrin polymers. Chem. Lett. 38 (2009) 1164-1165.

[3] M.J. Shieh, C.L. Peng, P.J. Lou, C.H. Chiu. Tsai, T.Y. Hsu, C.Y. Yeh and P. S. Lai, Non-toxic phototriggered gene transfection by PAMAM-porphyrin conjugates. J. Control Release 7 (2008) 200-206.

[4] C.-T. Poon, S. Zhao, W.-K. Wong and D.W.J. Kwong, Synthesis, excitation energy transfer and singlet oxygen photogeneration of covalently linked N-confused porphyrin-porphyrin and Zn(II) porphyrin dyads, Tetrahedron Lett. 51 (2010) 664668.

[5] S. Mettath, B. R. Munson and R.K. Pandey, DNA interaction and photocleavage properties of porphyrins containing cationic substituents at the peripheral position, Bioconjugate Chem. 10 (1999) 94-102.

[6] R.F. Pasternack, E.J. Gibbs and J.J. Villafranca, Interactions of porphyrins with nucleic acids, Biochemistry 22 (1983) 2406-2414.

[7] A. D'Urso, A. Mammana, M. Balaz, A.E. Holmes, N. Berova, R. Lauceri and R. Purrello, Interactions of a tetraanionic porphyrin with DNA: From a Z-DNA sensor to a versatile supramolecular device, J. Am. Chem. Soc. 131 (2009) 2046-2047.

[8] R. J. Fiel, J. C. Howard and N. Datta Gupta, Interaction of DNA with a porphyrin ligand: evidence for intercalation, Nucl. Acids Res. 6 (1979) 3093-3118.

[9] R. J. Fiel, Porhpyrin-nucleic acid interactions: a review, J. Biomol. Struct. Dyn. 6 (1989) 1259-1273. 
[10] S. Far, A. Kossanyi, C. Verchère-Béaur, N. Gresn, E. Taillandier and M. PerréeFauvet, Bis- and tris-DNA intercalating porphyrins designed to target the major groove: Synthesis of acridylbis-arginyl-porphyrins, molecular modelling of their DNA complexes, and experimental tests, Europ. J. Org. Chem. 8 (2004) 1781-1797.

[11] P. Zhao, L.-C. Xu, J.-W. Huang, K.-C. Zheng, J. Liu, H.-C. Yu and L.-N. Ji, DNA binding and photocleavage properties of a novel cationic porphyrin-anthraquinone hybrid, Biophys. Chem. 134 (2008) 72-83.

[12] T.Jia, Z.-X. Jiang, K. Wang and Z.-Y. Li, Binding and photocleavage of cationic porphyrin-phenylpiperazine hybrids to DNA,Biophys. Chem. 119 (2006) 295-302.

[13] X. Chen, L. Hui, D.A. Foster and C. M. Drain, Efficient synthesis and photodynamic activity of porphyrin-saccharide conjugates: Targeting and incapacitating cancer cells, Biochemistry 43 (2004) 10918-10929.

[14] V. Duarte, S. Sixou, G. Favre, G. Pratviel and B.Meunier, Oxidative damage on RNA mediated by cationic metalloporphyrin-antisense oligonucleotides conjugates, $\mathrm{J}$. Chem. Soc. - Dalton Transactions 21 (1997) 4113-4118.

[15] M. Sibrian-Vazquez, T.J. Jensen, F.R. Fronczek, R.P. Hammer and M.G.H. Vicente, Synthesis and characterization of positively charged porphyrin-peptide conjugates, Bioconjugate Chem. 16 (2005) 852-863.

[16] M. Sibrian-Vazquez, T.J. Jensen and M.G.H. Vicente, Synthesis, characterization, and metabolic stability of porphyrin-peptide conjugates bearing bifunctional signaling sequences, J. Med. Chem. 51 (2008) 2915-2923. 
[17] L. Chaloin, P. Bigey, C. Loup, M. Marin, N. Galeotti, M. Piechaczyk, F. Heitz and B. Meunier, Improvement of porphyrin cellular delivery and activity by conjugation to a carrier peptide, Bioconjugate Chem. 12 (2001) 691-700.

[18] J. Nuno Silva, J. Haigle, J.P.C. Tomé, M.G.P.M.S. Neves, A.C. Tomé, J.-C. Mazière, C. Mazière, R. Santus, J.A.S. Cavaleiro, P. Filipe and P. Morlière, Enhancement of the photodynamic activity of tri-cationic porphyrins towards proliferating keratinocytes by conjugation to poly-S-lysine, Photoch. Photobiol. Sci. 5 (2006) 126-133.

[19] V. Sol, V. Chaleix, R. Granet and P. Krausz, An efficient route to dimeric porphyrin-RGD peptide conjugates via olefin metathesis, Tetrahedron 64 (2008) 364371.

[20] N. Gresh and M. Perrée-Fauvet, Major versus minor groove DNA binding of a bisarginylporphyrin hybrid molecule: A molecular mechanics investigation, J. Computer-Aided Mol. Design 13 (1999) 123-137.

[21] E. Biron and N. Voyer, Towards sequence selective DNA binding: Design, synthesis and DNA binding studies of novel bis-porphyrin peptidic nanostructures, Org. Biomol. Chem. 6 (2008) 2507-2515.

[22] K. Steenkeste, M. Enescu, F. Tfibel, P. Pernot, S. Far, M. Perrée-Fauvet and M.-P. Fontaine-Aupart, Structural dynamics and reactivity of a cationic mono(acridyl)bis(arginyl) porphyrin: A spectroscopic study down to femtoseconds, Phys. Chem. Chem. Phys. 6 (2004) 3299-3308.

[23] F. Hudecz and M. Szekerke, Investigation of drug-protein interactions and the drug-carrier concept by the use of branched polypeptides as model systems. 
Synthesis and characterization of the model peptides, Colect. Czech. Chem. Comm. 45 (1980) 933-940.

[24] F. Hudecz, Design of synthetic branched-chain polypeptides as carriers for bioactive molecules, Anti-Cancer Drugs 6 (1995) 171-193.

[25] K. Zupan, L. Herenyi, K. Toth, Z. Majer and G. Csik, Binding of Cationic Porphyrin to Isolated and Encapsidated Viral DNA Analyzed by Comprehensive Spectroscopic Methods, Biochemistry 43 (2004) 9151-9159.

[26] K. Zupán, L. Herényi, T. Tóth, E. Egyeki and G. Csík, Binding of cationic porphyrin to isolated DNA and nucleoprotein complex - quantitative analysis of binding forms under various experimental conditions, Biochemistry 44 (2005) $15000-15006$.

[27] J. Habdas and B. Boduszek, Synthesis of new porphyrin-containing peptidyl phosphonates, Phosphorus, Sulfur Silicon 180 (2005) 2039-2045.

[28] J. Habdas and B. Boduszek, Synthesis of 5-(4'-carboxyphenyl)-10,15,20-tris-(4 pyridyl)-porphyrin and its peptidyl phosphonate derivatives, J. Peptide Sci. 15 (2009) 305-311.

[29] J.H. Strauss and R.L.J. Sinsheimer, Purification and properties of bacteriophage MS2 and of its ribonucleic acids, Mol. Biol. 7 (1963) 43-48.

[30] J.N. Demas and G.A. Crosby, The measurement of photoluminescence quantum yields, A review, J. Phys. Chem. 75 (1971) 991-1024.

[31] A.S. Ito, G.C. Azzellini, S.C. Silva, O. Serra and A.G Szabo, Optical absorption and fluorescence spectroscopy studies of ground state melanin-cationic porphyrins complexes, Biophys. Chem. 45 (1992) 79-89. 
[32] E. Reddi, M. Ceccon, G. Valduga, G. Jori, J.C. Bommer, F. Elisei, L. Latterini and U. Mazzucato, Photophysical properties and antibacterial activity of mesosubstituted cationic porphyrins, Photochem. Photobiol. 75 (2002) 462-470.

[33] M. Momenteau and B. Loock, E. Bisagni, Preparation and characterization of a new meso-substituted tetrapyrrole macrocyclc: Meso-tetra[2-(3carboxyethyl)furyl]porphine, [TF $\left.\mathrm{TO} 2 \mathrm{Et}_{\mathrm{P}} \mathrm{P}\right]$, J. Heterocyclic Chem. 16 (2009) 191-192.

[34] J.M. Kelly, M.J. Murphy, D.J. McConnell and C. Uigin, A comparative study of the interaction of 5,10,15,20-tetrakis(Nmethylpyridinium-4-yl)porphyrin and its zinc complex with DNA using fluorescence spectroscopy and topoisomerisation, Nucleic Acids Res. 13 (1985) 167-184.

[35] M.A. Sari, J.P. Battioni, D. Dupre, D. Mansuy and J.B. Le-Pecq, Interaction of cationic porphyrins with DNA: importance of the number and position of the charges and minimum structural requirements for intercalation, Biochemistry 29 (1990) 4205-4215.

[36] R.F. Pasternack, C. Bustamante, P.J. Collings, A. Giannetto and E.J. Gibbs, Porphyrin assemblies on DNA as studied by a resonance light-scattering technique, J. Am. Chem. Soc. 115 (1993) 5393-5399.

[37] S. Lee, S. H. Jeon, B.-J. Kim, S.W. Han, H.G. Jang and S.K. Kim, Classification of CD and absorption spectra in the Soret band of H2TMPyP bound to various synthetic polynucleotides, Biophys. Chem. 92 (2001) 35-45.

[38] Y. Shen, P. Myslinski, T. Treszczanovicz, Y. Liu and J.A. Koningstein, Picosecond laser-induced fluorescence polarization studies of mitoxantrone and tetrakisporphine/DNA complexes, J. Phys. Chem. 96 (1992) 7782-7787. 
[39] J.B. Le Pecq and J. Paoletti, A fluorescent complex between ethidium bromide and nucleic acids, J. Mol. Biol. 27 (1967) 87-106.

[40] K. Lang, P. Anzenbacher, Jr., P. Kapusta, V. Kral, P. Kubat and D.M. Wagnerova, Long-range assemblies on poly $(\mathrm{dG}-\mathrm{dC})_{2}$ and poly $(\mathrm{dA}-\mathrm{dT})_{2}$ : Phosphonium cationic porphyrins and the importance of the charge, J. Photochem. Photobiol. B:Biol. 57 (2000) 51-59.

[41] X. Chen and M. Liu, Induced chirality of binary aggregates of opposite charged water-soluble porphyrins on DNA matrix, J. Inorg. Chem. 94 (2003) 106-113.

[42] U. Sehlstedt, S.K. Kim, P. Carter, J. Goodisman, J.F. Vollano, B. Norden and J.C. Dabrowiak, Interaction of cationic porphyrins with DNA, Biochemistry 33 (1994) $417-426$.

[43] M. Sibrian-Vazquez, T.J. Jensen, F.R. Fronczek, R.P. Hammer and M.G.H. Vicente Synthesis and characterization of positively charged porphyrin-peptide conjugates, Bioconjugate Chem. 16 (2005) 852-863.

[44] L. Chaloin,-P. Bigey, Ch. L., M. Marin, N. Galeotti, M. Piechaczyk, F. Heitz and B. Meunier, Improvement of porphyrin cellular delivery and activity by conjugation to a carrier peptide, Bioconjugate Chem. 12 (2001) 691-700.

[45] P. Dozzo, M.-S. Koo, S. Berger, T.M. Forte and S.B. Kahl. Synthesis, Characterization, and Plasma Lipoprotein Association of a Nucleus-Targeted Boronated Porphyrin, J. Med. Chem. 48 (2005) 357-359.

[46] E. Biron and N.Voyer, Towards sequence selective DNA binding: Design, synthesis and DNA binding studies of novel bis-porphyrin peptidic nanostructures, Org. Biomol. Chem. 6 (2008) 2507-2515. 
[47] R. F. Pasternack, Circular dichroism and the interactions of water soluble porphyrins with DNA—A minireview, Chirality 15 (2003) 329-332.

[48] A.B. Guliaev and N.B. Leontis, Cationic 5,10,15,20-tetrakis (N-methylpyridinium4-yl) porphyrin fully intercalates at 5'-CG-3' steps of duplex DNA in solution, Biochemistry 47 (1999) 15425-15437.

[49] S. Mohammadi, M. Perree-Fauvet, N. Gresh, K. Hillairet and E. Taillandier, Joint molecular modeling and spectroscopic studies of DNA complexes of a bis(arginyl) conjugate of a tricationic porphyrin designed to target the major groove, Biochemistry 37 (1998) 6165-6178.

[50] L.A. Lipscomb, F.X. Zhou, S.R. Presnell, R.J. Woo, M.E. Peek R.R. Plaskon and L.D. Willians, Structure of DNA-porphyrin complex, Biochemistry 35 (1996) 28182823.

[51] N.N. Kruk, S.I. Shishporenok, A.A. Korotky, V.A. Galievsky, V.S. Chirvony and P. Turpin, Binding of the cationic 5,10,15,20-tetrakis(4- $N$-methylpyridyl) porphyrin at $5^{\prime} \mathrm{CG} 3^{\prime}$ and $5^{\prime} \mathrm{GC}^{\prime}$ sequences of hexadeoxyribonucleotides: triplettriplet transient absorption, steady-state and time-resolved fluorescence and resonance Raman studies, J. Photochem. Photobiol. B: Biol. 45 (1998) 67-74. 


\section{Figure legends}

Fig. 1. Structure of porphyrin conjugates: (A) $\mathrm{NH}_{2}-$ Lys(TMPCP-Ala-D-Ala-Ala)$\mathrm{CONH}_{2}$, (TMPCP-4P) and (B) $\mathrm{NH}_{2}$-Lys[Lys(Ala-D-Ala-Ala-BMPCP)BMPCP-Ala-DAla-Ala) $]-\mathrm{CONH}_{2}\left(\mathrm{BMPCP}-4 \mathrm{P}_{2}\right)$

Fig. 2. (A) Normalized absorption spectra of TMPCP in Tris- $\mathrm{HCl} \mathrm{pH} 7.4$ (black) and methanol (red). (B) Soret bands of normalized absorption spectra of TMPCP (black), TMPCP-4P (magenta), BMPCP (blue) and BMPCP-4P 2 (green) recorded in Tris-HCl buffer $\mathrm{pH} 7.4$.

Fig. 3. Normalized fluorescence emission spectra of (TMPCP-4P) in Tris-HCl pH 7.4 (black) and methanol (blue) without DNA and in Tris- $\mathrm{HCl} \mathrm{pH} 7.4$ in the presence of DNA (red). The concentration of porphyrin and of base pairs was $1 \mu \mathrm{M}$; and $15 \mu \mathrm{M}$, respectively. The samples were excited at the corresponding absorption maxima.

Fig. 4. (A) Absorption spectra of BMPCP-4P $\mathrm{P}_{2}$ at various concentration of DNA. Base pair/porphyrin molar ratio $(r)$ varies between 0 and 10. (B) Decomposition of the Soret band of the absorption spectrum of BMPCP $-4 \mathrm{P}_{2}$ recorded at $r=10$ (open symbols).

Component absorption bands are identified by the position of corresponding maxima. Orange line shows the sum of the components; residual plot is presented at 0 . Parameters of the components are shown in Table 3.

Fig. 5. Relative area of the components of the absorption spectra of (A) TMPCP (open symbols) and TMPCP-4P (filled symbols) and (B) BMPCP (open symbols) and BMPCP-4P 2 (filled symbols) as a function of base pair/porphyrin molar ratio $(r)$ in DNA. Absorption bands are identified by the position of corresponding maxima indicated in the Figure. 
Fig. 6. Integrated relative fluorescence intensity of TMPCP (black), TMPCP-4P (magenta), BMPCP (blue) and BMPCP-4P ${ }_{2}$ (green) upon excitation at $\lambda=260 \mathrm{~nm}$ as the function of the DNA base pair/porphyrin molar ratio $(r)$. The concentration of porphyrin was $1 \mu \mathrm{M}$.

Fig. 7. CD spectra of TMPCP (black), TMPCP-4P (magenta), and BMPCP-4P (green) $^{2}$ in the presence of free DNA at $r=30$. The concentration of porphyrin was $1 \mu \mathrm{M}$. 
Table 1. RP-HPLC and ESI-MS characteristics of porphyrin derivatives and their peptide conjugates.

\section{Compounds}

Ac-Lys(Ala-D-Ala-Ala)- $\mathrm{NH}_{2}$

BMPCP

BMPCP-4P 2

TMPCP

TMPCP-4P

\section{RP-HPLC ${ }^{\text {a }}$ \\ $\mathbf{R}_{\mathrm{t}}$ (min)}

12.8

29.2

24.2

29.8

28.3
Mw ${\text { (calculated })^{b}}^{b}$

400.5

734.8

1499.8

706.8

1089.3
Mw (measured)

400.4

734.8

1500.0

706.8

1089.3

${ }^{a}$ Column: Phenomenex Jupiter C18 (250 mm x $4.6 \mathrm{~mm}, 5 \mu \mathrm{m}, 300 \AA$ ); Eluents: 0.1\%TFA/water (A), $0.1 \% \mathrm{TFA} /$ acetonitrile-water $(80: 20, \mathrm{v} / \mathrm{v})(\mathrm{B})$; Gradient: 0 min $0 \% \mathrm{~B} ; 5 \mathrm{~min} 0 \% \mathrm{~B} ; 50 \mathrm{~min} 90 \% \mathrm{~B}$;

Flow rate: $1 \mathrm{~mL} / \mathrm{min}$; Detection: $\lambda=220 \mathrm{~nm}$

${ }^{\mathrm{b}}$ Average molecular masses 
Table 2. Spectroscopic properties of porphyrins in monomeric state in methanol and in Tris- $\mathrm{HCl} \mathrm{pH}$ 7.4: centers of Soret and $\mathrm{Q}_{x}(0,0)$ bands $\left(\lambda_{S}\right.$ and $\left.\lambda_{R}\right)[\mathrm{nm}]$ with the corresponding molar extinction coefficients $(\varepsilon)\left[\mathrm{M}^{-1} \mathrm{~cm}^{-1}\right]$, fluorescence emission $\operatorname{maxima}\left(\lambda_{\max }\right)[\mathrm{nm}]$, fluorescence lifetimes $(\tau)[\mathrm{ns}]$ and fluorescence quantum yields $\left(\Phi_{F}^{S}\right)$

\begin{tabular}{|c|c|c|c|c|c|c|c|c|}
\hline Compounds & Solvent & $\lambda_{\mathrm{s}}$ & $\varepsilon$ & $\lambda_{R}$ & $\varepsilon$ & $\lambda_{\max }$ & $\tau_{\mathrm{F}}$ & $\Phi_{F}^{S}$ \\
\hline \multirow[t]{2}{*}{ BMPCP } & Methanol & 421 & $1.59 \times 10^{5}$ & 645 & $1.37 \times 10^{3}$ & 708 & 9.82 & 0.02 \\
\hline & $\begin{array}{l}\text { TRIS } \\
\text { buffer }\end{array}$ & 418 & $1.7 \times 10^{5}$ & 646 & $9.70 \times 10^{2}$ & 698 & 8.76 & 0.018 \\
\hline \multirow[t]{2}{*}{ BMPCP- $4 \mathrm{P}_{2}$} & Methanol & & $2.37 \times 10^{5}$ & 646 & $1.51 \times 10^{3}$ & 708 & 10.4 & 0.02 \\
\hline & $\begin{array}{l}\text { TRIS } \\
\text { buffer }\end{array}$ & & & 638 & $9.65 \times 10^{2}$ & 700 & 8.99 & 0.018 \\
\hline \multirow[t]{2}{*}{ TMPCP } & Methanol & 426 & $4.02 \times 10^{5}$ & 651 & $1.75 \times 10^{3}$ & 660 & 8.17 & 0.03 \\
\hline & $\begin{array}{l}\text { TRIS } \\
\text { buffer }\end{array}$ & 422 & $1.86 \times 10^{5}$ & 641 & $1.28 \times 10^{3}$ & 694 & 4.2 & 0.017 \\
\hline \multirow[t]{2}{*}{ ТМРCP-4P } & Methanol & 426 & $4.62 \times 10^{5}$ & 647 & $1.49 \times 10^{4}$ & 659 & 8.16 & 0.03 \\
\hline & $\begin{array}{l}\text { TRIS } \\
\text { buffer }\end{array}$ & 423 & $9.8 \times 10^{4}$ & 644 & $1.86 \times 10^{3}$ & 697 & 4.9 & 0.018 \\
\hline
\end{tabular}


Table 3. Fitted parameters of the components of Soret bands $(370-490 \mathrm{~nm})$ in Tris-HCl buffer $(\mathrm{pH} 7.4): \lambda_{\mathrm{i}}(\mathrm{nm})$ is the center of the peak, $w_{\mathrm{i}}(\mathrm{nm})$ is the full width of the band. Index 1-2 refers the parameters received for free porphyrins, index 3-4 refers the parameters received in the presence of DNA. Errors are less than $1 \mathrm{~nm}$ for $\lambda_{\mathrm{i}}$, and less than $0,5 \mathrm{~nm}$ for $w_{\mathrm{i}}$.

\begin{tabular}{|c|c|c|c|c|c|c|c|c|}
\hline Compounds & $\lambda_{1}$ & $w_{1}$ & $\lambda_{2}$ & $w_{2}$ & $\lambda_{3}$ & $w_{3}$ & $\lambda_{4}$ & $w_{4}$ \\
\hline ВМРСР & 407 & 17 & 418.5 & 13.5 & 429 & 7 & 435 & 14 \\
\hline BMPCP-4P ${ }_{2}$ & 407 & 15 & 418.5 & 11 & 429 & 11 & 435 & 16 \\
\hline ТМРСР & 402 & & 422 & 17.5 & 429 & 25 & 446 & 25 \\
\hline TMPCP-4P & 402 & & 422 & 17.5 & 429 & 25 & 446 & 25 \\
\hline
\end{tabular}


Table 4. Fluorescence lifetimes $(\tau)(\mathrm{ns})$ of

porphyrin derivatives and peptide conjugates in the presence of T7 DNA at $r=6$

\begin{tabular}{lcc} 
Compounds & $\boldsymbol{\tau}_{1}$ & $\boldsymbol{\tau}_{2}$ \\
\hline BMPCP & $8.84 \pm 23$ & \\
BMPCP-4P & $2.36 \pm 0,12$ & - \\
TMPCP & $2.38 \pm 0,15$ & $8.64 \pm 0,12$ \\
TMPCP-4P & $3.46 \pm 0.18$ & $9.50 \pm 23$
\end{tabular}

Table 5. Charge composition of compounds, and the approximate base pair/porphyrin ratio $(r)$ at which the partition of free compound becomes negligible in the presence of DNA

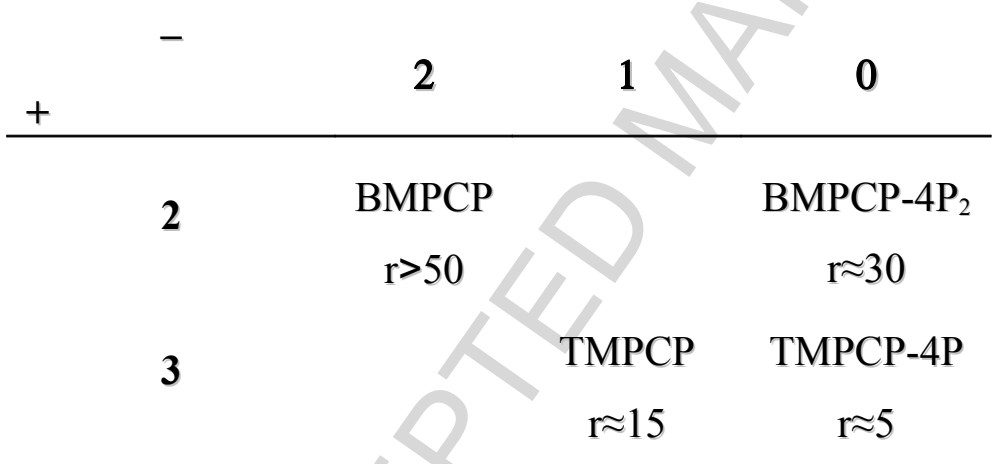


Fig 1
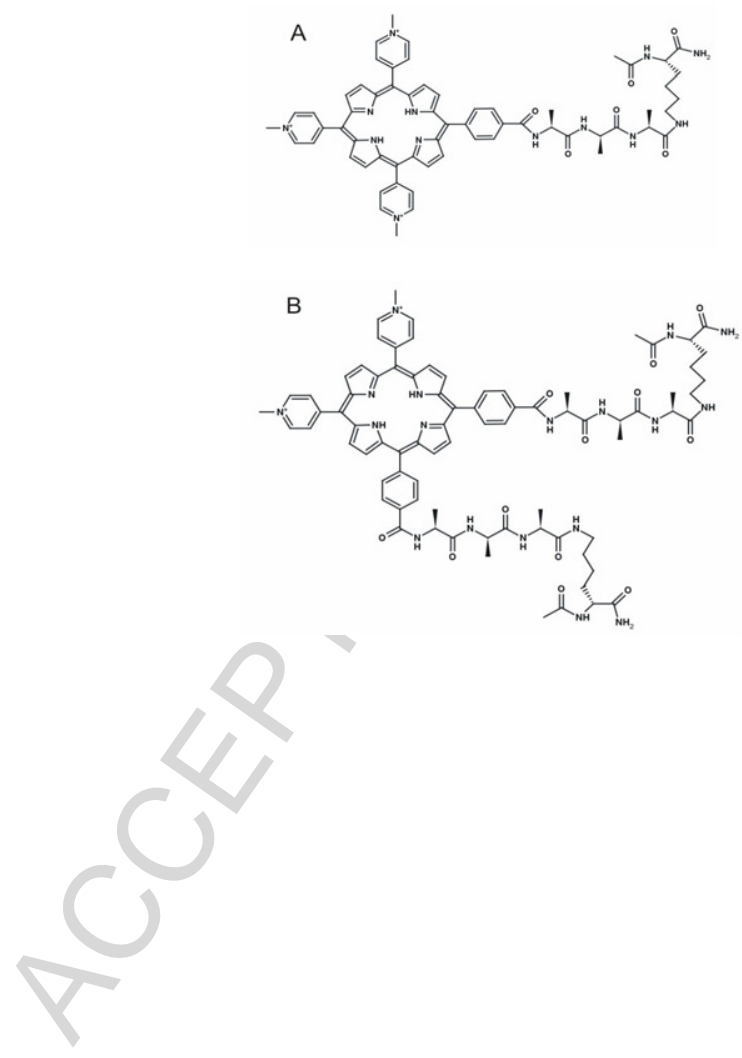
Fig 2
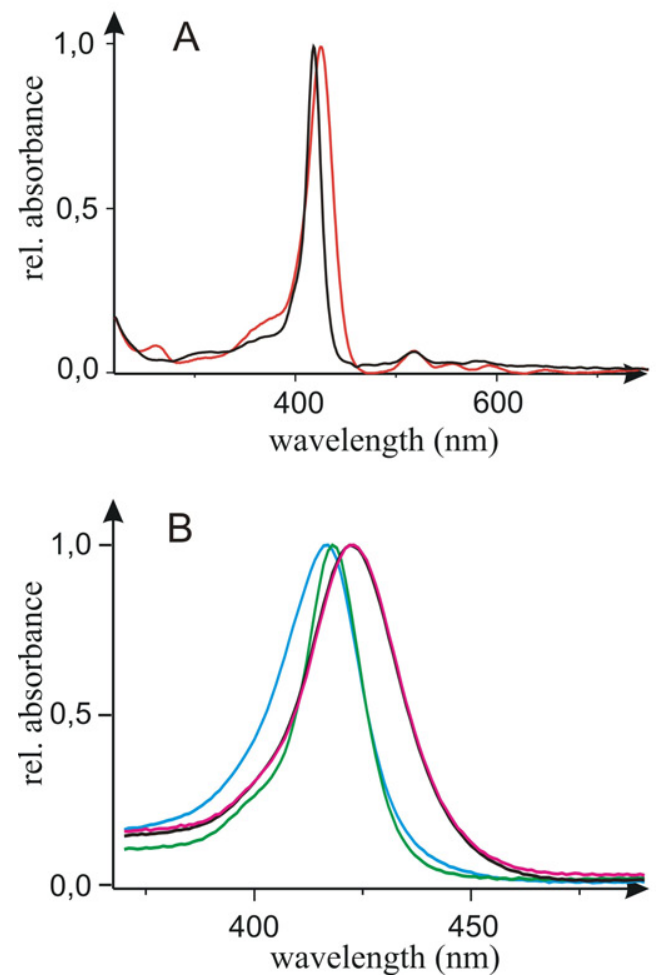
Fig 3

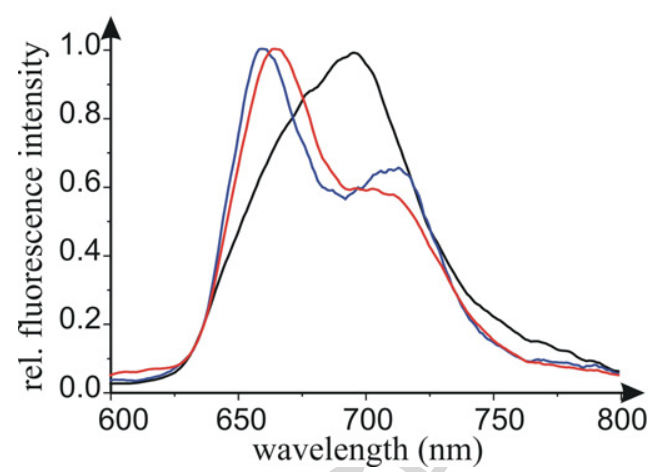


Fig 4
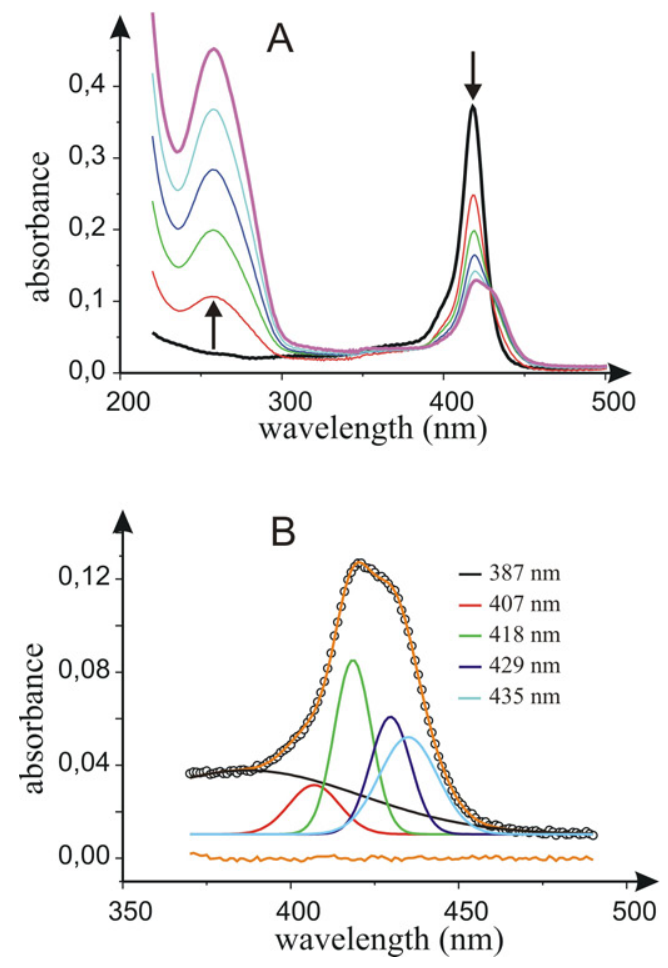
Fig 5
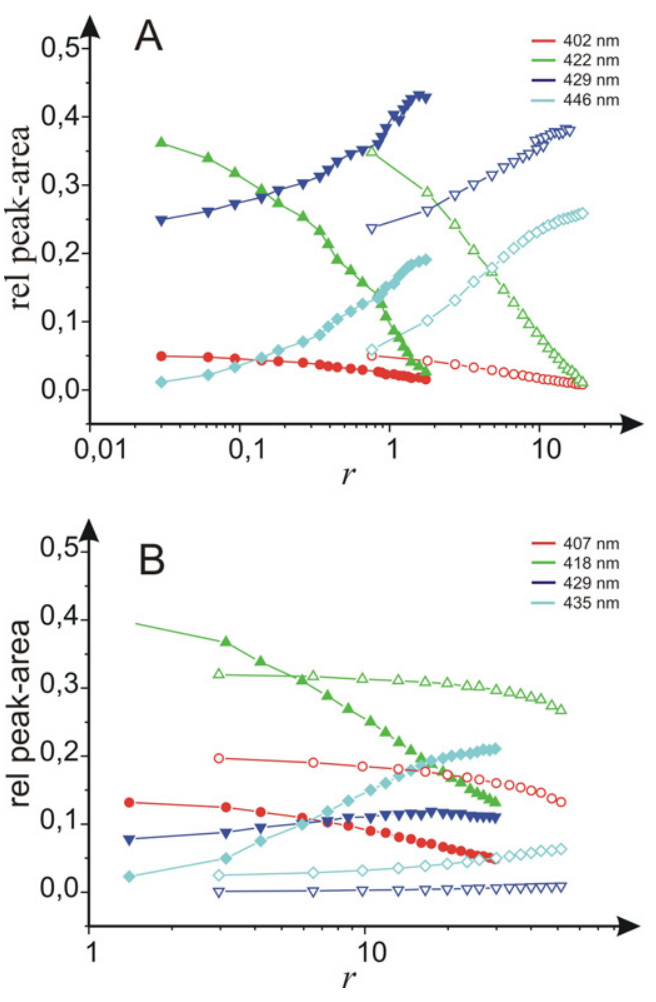
Fig 6

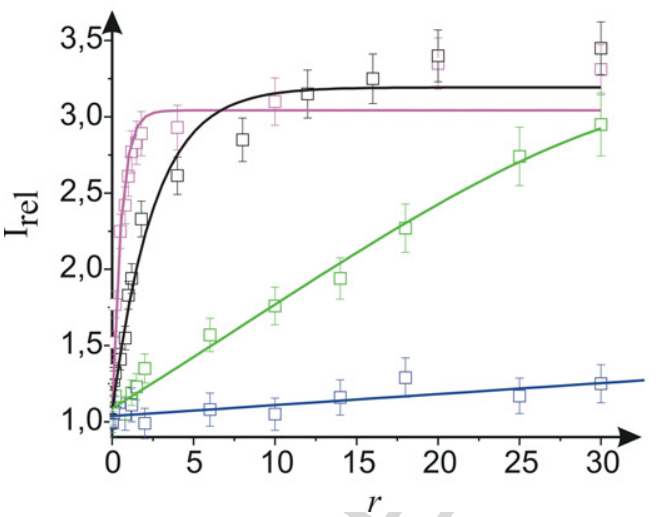


Fig 7

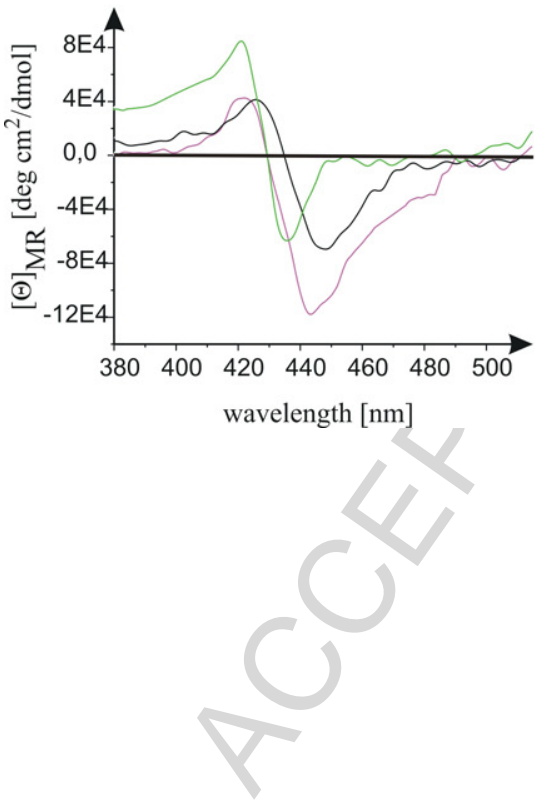

